\title{
Conservative Protestants and Wealth: How Religion Perpetuates Asset Poverty ${ }^{1}$
}

\author{
Lisa A. Keister \\ Duke University
}

\begin{abstract}
The association between cultural orientation and material outcomes is fundamental to sociology research. This article contributes to the understanding of this relationship by exploring how religious affiliation affects wealth ownership for conservative Protestants (CPs). The results demonstrate that religion affects wealth indirectly through educational attainment, fertility, and female labor force participation. The results also provide evidence of a direct effect of religion on wealth. Low rates of asset accumulation and unique economic values combine to reduce $\mathrm{CP}$ wealth beyond the effects of demographics. The findings improve understanding of the relationship between religious beliefs and inequality.
\end{abstract}

\begin{abstract}
Honor the Lord with your wealth, with the first fruits of all your crops; then your barns will be filled to overflowing, and your vats will brim over with new wine. (Prov. 3:9-10)

It would not be at all strange, therefore, if from these [Biblical] teachings and facts men should have concluded that the pursuit of wealth was unchristian and wealth itself an evil rather than a good. (Mathews 1896, p. 774)
\end{abstract}

The relationship between cultural orientation and material well-being is central to research in sociology, and concern about this relationship has fueled decades of intense debate regarding the material consequences of religious values (Darnell and Sherkat 1997; Featherman 1971; Greeley

\footnotetext{
${ }^{1}$ I am grateful for a grant from the National Institutes on Health (National Institute on Aging and National Institute of Child Health and Human Development) and the support of the Center for Advanced Study in the Behavioral Sciences at Stanford University. John Bartkowski, Jackie Brooks, Barry Chiswick, Christopher Ellison, William Form, Evelyn Lehrer, Jim Moody, Matthew Painter, and Christian Smith all provided helpful comments. Seminar participants at the Center for Advanced Study,

(C) 2008 by The University of Chicago. All rights reserved.

0002-9602/2008/11305-0001\$10.00
}

AJS Volume 113 Number 5 (March 2008): 1237-71

1237 


\section{American Journal of Sociology}

1969; Lenski 1961). Underlying much of this research is an assumption that religion is connected to worldly goods, or wealth. Wealth is among the most fundamental indicators of well-being because it is relatively enduring and is related in some way to most other measures of achievement. When it can be measured directly, wealth is net worth, or total household assets less total liabilities. Wealth can improve educational attainment, occupational opportunities, and political influence. It provides a financial buffer against the loss of a primary breadwinner's income, a medical emergency, or a natural disaster. Wealth can also be passed to future generations to extend these advantages indefinitely. Although the benefits of wealth are significant, they are not enjoyed uniformly in the United States because asset ownership is highly concentrated (Keister 2000, 2005; Wolff 2004). Between 1995 and 2004, mean net worth increased $72 \%$, to $\$ 448,000$, while the median increased only $31 \%$, to $\$ 93,000$. $^{2}$ In 2004 , the top $1 \%$ of households owned $33 \%$ of net worth, and the top $10 \%$ owned $70 \%$. At the same time, $16 \%$ of households had zero or negative net worth.

Recent research has revived interest in the association between cultural orientation and wealth by demonstrating that religion and asset ownership are correlated and that some religious groups are much more likely than others to experience persistent asset poverty (Keister 2003a, 2005). Notably, this research shows that conservative Protestants (CPs) are dramatically overrepresented in the bottom of the wealth distribution-particularly on measures of financial asset ownership_independent of family background (Keister 2003a, 2005). CPs are members of churches with relatively traditional religious beliefs who accept the Bible as the inerrant word of God, value personal conversion experiences, and emphasize the importance of the Christian faith to social issues (Sherkat and Ellison 1999; Woodberry and Smith 1998). Some of the larger and more widelyrecognized CP denominations are Assembly of God, Baptist, Churches of Christ, Church of God in Christ, Nazarene, and Pentecostal. ${ }^{3}$ At least $25 \%$ of the U.S. population belongs to a CP denomination (1998 General Social Survey), which suggests that the processes that lead to asset poverty

Duke University, the Society for the Scientific Study of Religion, the University of Chicago Graduate School of Business, and the University of California, Irvine, gave me valuable feedback. Matthew Painter and Alexis Yamokoski provided research assistance. Direct correspondence to Lisa Keister, Department of Sociology, Duke University, 268 Soc/Psych Building Durham, North Carolina 27708-0088. E-mail: lkeister@soc.duke.edu

${ }^{2}$ All values are in 2000 dollars. Author's estimates are from the Survey of Consumer Finances.

${ }^{3}$ Conservative Protestant denominations are sometimes called "Evangelical," but in reality Evangelicals are a subset of CPs (Smith 2000; Woodberry and Smith 1998). 
for this group may inform understanding of more general patterns in wealth distribution.

While there is evidence that religion and wealth are related, what is missing is a clear account of the process by which religion affects the wealth of believers. This paper fills this gap by studying why CPs accumulate low wealth. I propose that limited educational attainment, early fertility, large family size, and low rates of female labor force participation are important demographic contributors to low $\mathrm{CP}$ wealth. I also propose that there is a direct effect of $\mathrm{CP}$ religious belief on wealth, net of these demographic behaviors, that results from low rates of asset accumulation over time. I then identify the unique economic values that follow from $\mathrm{CP}$ religious beliefs and that lead to low accumulation. I use the National Longitudinal Survey of Youth, 1979 cohort (NLSY) and the Economic Values Survey (EVS) to study these ideas empirically. The NLSY provides detailed longitudinal data on family background, education, adult family traits, and wealth. The EVS contributes comprehensive measures of the values and religious beliefs that affect wealth.

\section{RELIGIOUS AFFILIATION AND WEALTH}

The cultural understandings that accompany religious belief can influence wealth ownership indirectly through behaviors that facilitate or impede asset accumulation. Religion affects orientations toward education and educational attainment (Darnell and Sherkat 1997; Lehrer 1999). It influences sexuality and fertility, including such factors as the onset of sexual activity, the age of a woman at her first birth, and family size (Marcum 1981, 1986; Sherkat and Ellison 1999). Religion affects parenting styles and relationships between parents and their children (Bartkowski and Ellison 1995; Ellison, Bartkowsi, and Segal 1996; Ellison and Sherkat 1993). There is also a strong relationship between religion and gender roles (Hertel and Hughes 1987; Peek, Lowe, and Williams 1991), including female educational attainment and labor force participation (Lehrer 1995; Sherkat 2000). As a result, religion is likely to affect occupational advancement, income, other financial benefits, the availability of funds to save, and ultimately wealth ownership.

Religion can also influence wealth ownership directly by shaping the values that people use to make work and financial decisions (Keister 2003a; Swidler 1986). Values are ideals that express the worth associated with actions and outcomes, and the shared cultural understandings that accompany religious beliefs influence values. Religious beliefs attribute value to working for certain organizations and in some occupations. Religious beliefs also attribute value to saving, sacrificial giving, and other 
American Journal of Sociology

behaviors that directly involve money. The value associated with particular work and financial behaviors varies dramatically by faith, but there is little question that money is meaningful, that values and finances are intimately connected, and that Americans recognize that there is a connection (Wuthnow 1994; Zelizer 1978, 1989).

Finally, religion affects wealth through social contacts. People learn how to save from their parents and others they encounter as children (Chiteji and Stafford 2000). Strategies for saving and for avoiding debt and work behaviors that facilitate saving are largely learned. People who are not exposed to these behaviors at home, in church, or in school may be at a disadvantage in accumulating wealth. Religion may also create social contacts who can provide information (e.g., about business opportunities) or capital (e.g., for investing) that facilitate wealth ownership. In contrast, in faiths where personal saving is limited, these advantages are likely to be lacking.

The value of education.-Low educational attainment is an important reason for low $\mathrm{CP}$ wealth. There is long-standing evidence that religion affects education (Glenn and Hyland 1967; Greeley 1969; Lenski 1961), and recent research shows that CPs complete comparatively low levels of schooling (Darnell and Sherkat 1997; Sherkat and Ellison 1999). CP cultural orientations tend to be at odds with the approaches of nonreligious schools and universities that propagate secular humanist values (Sikkink 1999) and promote scientific investigation rather than acceptance of divine truths (Darnell and Sherkat 1997). As a result, some CPs home-school their children or send them to Christian schools (Sherkat and Ellison 1999). While the majority of CPs have remained involved in public schools (Sherkat and Ellison 1999), they appear to follow advice from church leaders who discourage attendance at secular colleges and universities. As a result, educational attainment for CPs is significantly lower than for members of other faiths (Darnell and Sherkat 1997), declining most noticeably after high school (Lehrer 1999). Because education is one of the strongest predictors of wealth and because it also affects other correlates of wealth (e.g., family size, female labor force participation, income), I expect that low educational attainment reduces wealth for CPs.

Family values and asset values.-Family behaviors also predispose CPs to low wealth. CPs have children relatively early (Pearce 2002) and tend to have large families (Lehrer 1996; Marcum 1981, 1986). Having children at any age reduces wealth because saving becomes more difficult. Early fertility exacerbates the effect because it limits schooling, career development, and initial saving and investing that can contribute to lifelong asset appreciation (Keister 2005). Family size can also reduce asset accumulation. There is a curvilinear relationship between family size and wealth: wealth increases somewhat in families with one to two children 
(compared to households with no children) as parents increase their saving and buy homes, but it then declines significantly in families with more than two children as expenses rise (Keister 2005). Moreover, because they tend to value a relatively traditional division of labor (Ellison and Bartkowski 2002; Gallagher and Smith 1999), CP women participate in paid work outside the home at low rates, particularly when their children are young (Lehrer 1995). Single-earner households-typically households in which the adult female is not employed outside the home-tend to have low income and limited resources available to save (Steen 1996). For these reasons, I expect that early fertility, large family size, and low rates of female labor force participation reduce wealth for CPs.

Saving and asset accumulation.-Saving from current income and resulting asset growth are perhaps the two best predictors of total adult wealth. In fact, discussions of the behaviors that affect wealth usually imply that these behaviors affect saving, even if the connection is not explicit. CP education and family behaviors will reduce the availability of funds to save. There may also be an intergenerational effect on saving for CPs. People learn to save from their parents and other family members (Chiteji and Stafford 1999, 2000), and a large majority of CPs remain affiliated with their childhood religion as adults or return to their childhood religion after a brief departure (Roof 1989; Sherkat 1991). As a result, saving is likely to have been low in prior generations of CPs, for the same demographic reasons why it is low in current generations. As these patterns cumulate across generations, they will reduce active saving in each generation, and the resulting low wealth will diminish asset transfers across generations. Finally, CPs are unlikely to marry people of other religions and thus unlikely to expand their repertoire of skills and strategies by marrying someone with a different tool kit (Kalmijn 1991; Thornton 1985). As a result, I expect that because they save less from current income, CPs accumulate assets relatively slowly.

Economic values.-The majority of Americans draw a conscious connection between their religious beliefs and their financial and work behaviors (Wuthnow 1994), and CPs are particularly explicit in linking attitudes toward money and spiritual well-being. According to a prominent CP commentator, "The scripture makes clear that there is a fundamental connection between a person's spiritual life and his attitudes and actions concerning money and possessions" (Alcorn 2005, p. 3). The Bible contains a large number of lessons regarding money and finances: 16 of the 38 parables and $10 \%$ of New Testament verses address money or finances. There are approximately 500 total verses each on prayer and the importance of faith in the Bible, but there are more than 2,000 verses that deal with money and finances (Kreider 2002). Alcorn estimates that " 15 percent of everything Jesus said related to money and possessions. 


\section{American Journal of Sociology}

Our Lord made more references to money and possessions than to either prayer or faith. He spoke about money and possessions more than heaven and hell combined" (Alcorn 2005, p. 4).

A central defining trait of CPs is their interpretation of the Bible as the inerrant word of God. A key assumption that follows and that figures prominently in CP financial values is that money belongs to God, and people are managers of God's money. The Bible includes many references to God's exclusive ownership of worldly goods: "The land must not be sold permanently, because the land is mine and you are but aliens and tenants" (Lev. 25:23). "To the Lord your God belong the highest heavens, the earth and everything in it" (Deut. 10:14). "The earth is the Lord's, and everything in it, the world, and all who live in it" (Ps. 24:1). "Every animal of the forest is mine, and the cattle on a thousand hills. I know every bird in the mountains, and the creatures of the field are mine. If I were hungry I would not tell you, for the world is mine, and all that is in it" (Ps. 50:10-12). Conservative Protestants interpret such passages to mean that people are not the true owners of worldly possessions. Rather, God has entrusted people with the objects they possess, including both real and financial objects. Larry Kreider (2002, p. 9) explains: "We must realize that everything we have belongs to God. We are merely stewards (managers) of any material goods we possess. God owns everything we have, but He makes us managers of it." Similarly, according to Alcorn (2003a, p. xi), "We are God's money managers. He wants us to invest his money in his kingdom."

Three important values and associated practices follow from the assumption that God owns everything, and each of these values is likely to directly reduce saving and asset accumulation for CPs. The first value is that divine advice, advice from clergy, and other religiously oriented advice about money and work have important merit. Given that God owns all worldly possessions, it is prudent to seek his advice when making decisions about how to accumulate and handle those possessions (Alcorn 2003b; Burkett 2001; Kreider 2002). Seeking advice from clergy and their advice manuals follows as well because clergy are agents of God (Alcorn 2003b; Kreider 2002). As a result, I expect that CPs seek divine guidance in making financial and work decisions.

The second value that follows from the assumption that money belongs to God is that excess accumulation is undesirable. CPs articulate three reasons to avoid excess accumulation. First, there is a danger of becoming overly focused on material well-being at the expense of spiritual wellbeing. "No servant can serve two masters. Either he will hate the one and love the other, or he will be devoted to the one and despise the other. You cannot serve both God and Money" (Luke 16:10-13). The Bible also notes that the "love of money is the root of all kinds of evil" (1 Tim. 6: 
10), that people "who want to get rich fall into temptation" (1 Tim. 6:9), and that "a man's life does not consist in the abundance of his possessions" (Luke 12:15). That is, savings can be distracting. "People who place their money in stocks immediately check out the stock market page whenever they receive their daily newspaper. Why? Because that is where their interests lie; they are concerned about where their finances are placed. Where we give both our tithes and our offerings shows what we place value on" (Kreider 2002, p. 29). Second, excess accumulation is a bad investment. "Christ's primary argument against amassing material wealth isn't that it's morally wrong, but simply that it's a poor investment. Material things . . . cannot escape the coming fire of God that will consume the material world" (Alcorn 2003a, p. 18). Finally, it is not necessary to accumulate worldly possessions because God will take care of believers after they die. "When we invest money now in God's kingdom, we will receive great rewards later in heaven. . . . We provide tangible assets in heaven by giving away tangible assets on earth" (Alcorn 2003a, p. 21). This suggests that CPs avoid excess material accumulation.

A third value that follows from the assumption that God owns all material goods is that it is necessary to give some money back to God and to otherwise use money to do God's works. The Bible indicates that "from everyone who has been given much, much will be demanded; and from the one who has been entrusted with much, much more will be asked" (Luke 12:48) and that "with the measure you use, it will be measured you" (Matt. 7:2). CPs conclude that God wants to bless his followers materially but that the "real purpose for receiving God's prosperity is to expand the kingdom of God" (Kreider 2002, p. 13). Sacrificial giving is considered an investment in eternal rewards. "When we see our lives through the lens of eternity, our attitude toward wealth will change dramatically. When money and possessions are invested in heavenly treasure rather than earthly, the equation changes radically. The investment takes on eternal value" (Alcorn 2003a, p. 47). Most CP churches advocate tithing $10 \%$ of total family income, and many also suggest using additional funds (offerings) to support other religious organizations such as missions, shelters, and local outreach programs. Tithes should be made on all income, including earned income, transfer payments, business income, and gifts (Alcorn 2003b). While there is likely to be variance in the degree to which CPs heed warnings about tithing, other literature suggests that interpreting the Bible as the inerrant word of God leads to relatively generous tithing (Hoge et al. 1999; Regnerus, Smith, and Sikkink 1998). For these reasons, I expect that CPs value religious giving and contribute generously to religious organizations at all income levels. 


\section{American Journal of Sociology}

Overview of Modeling Strategy

I modeled these ideas in three steps. First, I modeled adult family net worth as a function of childhood religion. The results (table 1) include (1) a base model with childhood religion indicators and control variables to document that people raised in CP families have low adult wealth; (2) a model that adds education and family traits to the base model to examine arguments that these factors contribute to low wealth for CPs; (3) a model that includes separate indicators for black and white CPs to distinguish religion and race effects; and (4) a model that adds a control for inheritance - a restrictive model, given that inherited funds become part of total net worth and are largely included in the dependent variable. Second, I used two sets of models to explore the mechanisms underlying the relationship between religion and total wealth (table 2). I modeled adult family net worth as a function of (1) adult religion and (2) religious change between childhood and adulthood. Third, I modeled asset growth as a function of childhood religion to evaluate my proposal that CPs accumulate assets slowly and to begin assessing my proposal that CPs avoid excess accumulation (table 3). Finally, I modeled the relationship between religion and measures of financial values that lead to low accumulation and low wealth, including seeking divine guidance in financial and work decisions, avoiding accumulation, and sacrificial giving (table 4).

\section{DATA}

I used two data sets. First, I used the National Longitudinal Survey of Youth (NLSY) to model net worth and accumulation (tables 1-3). The Bureau of Labor Statistics administered the first NLSY to a nationally representative sample of 12,686 young adults (ages 14-22) in 1979. They conducted follow-up surveys yearly until 1994 and biennially until 2000, when respondents were ages 35-43. I used data on 6,111 members of the NLSY core sample. ${ }^{4}$ The NLSY includes detailed information about family background, transitions to adulthood, and adult traits. It also contains detailed religious affiliation data and wealth data starting in 1985, when the youngest respondents were age $20 .{ }^{5}$ The NLSY wealth modules include information on ownership (yes/no) and current value for a series of assets and debts. I used data from all survey years to create independent variables and wealth data from 12 years to create dependent variables

\footnotetext{
${ }^{4}$ Missing data reduced my sample size slightly, but I found no significant wealth or religion differences between my sample and the full sample. Experiments with imputing missing data did not change the results.

${ }^{5}$ The survey did not include wealth questions in 1991.
} 
(1985-90, 1992, 1993, 1995, 1996, 1998, and 2000). These data are ideal for this study because they are longitudinal, include a large representative sample, and contain detailed information about religion and wealth. The Survey of Consumer Finances (SCF) provides better cross-section estimates of wealth distribution, as it oversamples high-income households. The NLSY underestimates wealth values somewhat because it does not have a high-income oversample, but the underestimates are slight and longitudinal coverage is more important for this study. ${ }^{6}$

Second, I used the Economic Values Survey (EVS) to model financial and work values (table 4). The Gallup Organization administered the EVS in 1992 to 2,013 adults. Robert Wuthnow was the principal investigator of the survey, which included questions identified from in-depth interviews and submissions solicited from 100 religion scholars (Wuthnow 1994). Gallup used 1990 census data to identify a probability sample and weighted it to represent demographic traits of the U.S. adult labor force population. The survey includes detailed information about religious affiliation (consistent with NLSY data) and hundreds of questions about values regarding work, money, savings, and related topics. Because the sample includes only members of the labor force, it does not represent the entire population. Yet the sample is very similar to the population in terms of religious affiliation. Moreover, using a sample of working adults is likely to provide conservative (i.e., cautious) estimates of the relationship between religion and economic values. That is, if the sample included stay-at-home parents and others not in the labor force, responses would have been less likely to be biased in favor of my hypothesis. The EVS data are cross-sectional, an appropriate format for studying religion and economic values. Because the EVS data were collected in 1992, they represent religious values that were typical when the NLSY sample was fully engaged in saving.

\section{Model Details}

Net worth.-To model net worth (tables 1 and 2), I used NLSY data. I created pooled cross-section time series data with person-years as the unit of analysis to take advantage of the longitudinal nature of the data. The data included one observation per respondent per year, and both the dependent and independent variables were able to vary yearly for each respondent. I used likelihood-based general linear regression because the White's test for heteroscedasticity was significant, and the ordinary Durbin-Watson test $(D-W)$ for first-order autocorrelation was significantly different from two. Because the ordinary $D-W$ was significant, it was not

${ }^{6}$ See Keister (2005) for a comparison of the SCF and NLSY data. 
American Journal of Sociology

necessary to use the general $D-W$ for high orders of autocorrelation (Greene 2003). I used SAS Proc Mixed to estimate the models, employing the estimator option to correct for heteroscedasticity (following Diggle, Liang, and Zeger [1994]) and assuming an AR(1) structure in correcting for autocorrelation. I omitted several outliers, but the omission did not affect the results.

Accumulation.-To model asset growth (table 3), I used NLSY data and multilevel growth models (Singer 1998). These models allow me to isolate the effect of religion on the growth in asset values over time during adulthood (1985-2000). I estimated these models in SAS Proc Mixed. The general structure of the multilevel growth models is the same as the net worth models described above, but the growth models treat both the intercept and the slope as random effects. This is equivalent to interacting specified individual-level effects with time (year). These models facilitate studying asset accumulation by providing estimates of the effects of covariates on both the initial value and the growth rate of the dependent variable (with other effects controlled). I included measures of (1) religion and (2) an interaction between religion and time. The interpretation is of (1) the effect of religious background on the initial (1985) value of net worth, other covariates controlled, and (2) the effect of religion on the growth rate of net worth (between 1985 and 2000), other covariates controlled. Again, the White's test was significant, and the ordinary $D-W$ indicated first-order autocorrelation. I corrected using the estimator option and assuming an $\mathrm{AR}(1)$ process.

Economic values.-To model the relationship between religion and the economic values and behaviors that affect saving (table 4), I used EVS data. I used logistic regression models of 20 dichotomous value indicators, and I used generalized least squares (GLS) regression models of the amount contributed to religious organizations. In the GLS model, the White's test and the ordinary $D-W$ indicated heteroscedasticity and firstorder autocorrelation, and I corrected using the estimator option and assuming an AR(1) process. I report results for two models for each dependent variable. Model 1 includes a single CP indicator, and model 2 includes separate indicators for white CPs and black CPs. I report odds ratios for the logistic regression equations and a regression coefficient for the GLS equation. All models control for the individual and family traits described below, but models that separate CPs by race do not include a separate race control. To conserve space, I do not report coefficient estimates for control variables. 
Conservative Protestants and Wealth

Variables

NLSY Dependent Variables.-Net worth is the value of total assets less the value of total debts in the respondent's adult family for each survey year between 1985 and 2000, adjusted to 2000 dollars using the Consumer Price Index. Assets include stocks and bonds, cash accounts, trusts, individual retirement accounts, 401(k) plans, certificates of deposit, the primary residence, other real estate, vehicles, and other possessions. ${ }^{7}$ The debts include mortgages on the primary residence, debt on other real estate, vehicle debt, and other debt. Net worth is skewed, as wealth ownership is concentrated. Yet logging the variable, double logging it, taking the square root, and otherwise transforming it did not reduce the skew because a large proportion of households have zero net worth. Because using the transformed variable did not change the results, I report results of analyses using unlogged net worth to ease interpretation. Using alternative definitions of wealth also did not change the results. That is, using gross assets (i.e., the sum of all assets not reduced by liabilities), total financial assets, total nonfinancial assets, total liabilities, and other measures of household wealth produced comparable results. Removing outliers also did not change the results substantively. Accumulation is yearly change in net worth.

NLSY Independent Variables.-I used a series of dichotomous indicators of religious affiliation. The NLSY asked about religious affiliation in 1979, 1982, and 2000. I used 1979 reports to code childhood religion and 2000 reports to code adult religion. Responses on the three measures are very similar, consistent with research that shows people are likely to remain affiliated with their childhood religion. The distribution of respondents across denominations is also consistent with other data sources, including the General Social Survey. I followed Steensland et al. (2000) rigorously in identifying $\mathrm{CPs}$ and in separating white and black CPs. ${ }^{8}$ Few blacks reported non-CP religious affiliations, but if they did, I included them in the appropriate non-CP group. The results are robust to other classification strategies. In all analyses, the omitted category is mainline Protestants and Catholics, although the results are also very robust to changes in that category. To measure religious mobility, I identify those who were (1) CP in both childhood and adulthood (remained), (2) CP as children but not as adults (left), or (3) not $\mathrm{CP}$ as children but became $\mathrm{CP}$ as adults (joined). Again, the omitted category for religious mobility anal-

\footnotetext{
${ }^{7}$ Excluding other possessions does not change the results significantly.

${ }^{8}$ Steensland et al. (2000) refer to conservative Protestants as Evangelicals. While our terminology is different, we are referring to the same group of churches.
} 
American Journal of Sociology

yses is mainline Protestants and Catholics, but the results are robust to changes in the omitted category.

Education is represented by a series of dichotomous variables indicating highest level completed. The omitted category includes those who did not complete high school. Using a continuous measure produces comparable results. I measured family processes with four variables: a dichotomous indicator that the respondent had any children and continuous indicators of the respondent's age at first birth, number of children, and number of children ${ }^{2}$. I include the square of family size to capture the curvilinear relationship between this variable and wealth. Including both the dichotomous and continuous indicators forces the continuous indicators to drop out of the equation when the respondent has no children. I included a dummy variable indicating whether the adult female in the household worked for pay outside the home to measure female labor force participation (two-earner household).

I controlled for race with dichotomous indicators that the respondent was black or Hispanic. Net family income in 1978 (childhood family income, logged) controls for childhood family resources, and a dummy variable indicating missing data on 1978 income controls for patterns among nonresponders (Sandefur and Wells 1999). I included two measures of family structure at age 14 (stepparent family, single-parent family) and total number of siblings to control resource dilution in large families (Downey 1995; Keister 2003b). I used dichotomous indicators to control parents' education, whether the respondent's parents both worked full time (more than 35 hours per week) in 1978, parents' immigrant status, and respondent's immigrant status.

To control intergenerational transfers, I included a dummy variable indicating whether the person ever received an inheritance and a continuous measure of the amount of inheritance by year (standardized, logged, and converted to 2000 dollars using the Consumer Price Index). The combination of parents' income, education, work behavior, and inheritance provides an excellent proxy for childhood wealth, which is not available in the NLSY. These variables capture both the parents' ability to generate wealth and the actual wealth they acquired, and these measures in turn account for most of the variance in parental assets (Keister 2005). Preliminary exploration using imputation, simulation, and synthetic measures of parents' wealth produced similar substantive outcomes.

I also controlled for male, age (years), and marital status (in the prior year). ${ }^{9}$ I controlled for total household income (prior year, logged) from

${ }^{9}$ I found no differences between unmarried and married people, consistent with my previous research on gender and wealth (Yamokoski and Keister 2005). I did not control for age squared, as there is typically not a curvilinear age-wealth relationship. My investigation confirmed that age squared was not significant here. 
sources other than public assistance, because religion affects income (Steen 1996). ${ }^{10}$ To measure socioeconomic class, I included three variables: (1) a measure of total public assistance income (logged) received in the prior year, (2) a measure of whether the respondent's occupation in the prior year was categorized as manual labor (laborer) using detailed census occupation codes, and (3) a dichotomous indicator of rural residence in the prior year. ${ }^{11}$ To create the measure of rural residence, I used census data to indicate whether the county of residence had a central core city and an adjacent, closely settled area with a total combined population of 50,000 or more. A set of three dummy variables indicates region of residence in the current year, including residence in north central states (Midwest), southern states (South), and western states (West), versus those living in northeastern states (East). ${ }^{12}$ (Appendix table A1 includes descriptive statistics for NLSY variables; the estimates are consistent with other published data.)

EVS dependent variables.-I report analyses using 21 dependent variables from the EVS, including 20 dichotomous variables (yes $=1$ ) and one continuous variable. This large selection of outcome variables provides broad insight into the orientations respondents have toward money and work. I present the results in four groups. The first group of outcomes are related to divine guidance in financial and work decision making. This group includes responses to questions regarding the purpose of church/synagogue, the role of God in providing financial blessings, the Bible's lessons regarding money, and the role of religion in career decisions. The second group of outcomes are related to accumulation. This group includes responses to questions regarding the meaning of money and the relationship between riches and closeness to God. The third group of outcomes are related to sacrificial giving. This group includes responses to questions regarding the role of sacrificial giving in religious participation, the importance of religious organizations as outlets for charitable giving, and responsibility toward the poor. The third group also includes a continuous measure of the amount contributed to church and synagogue in the prior year (1992 dollars, logged). ${ }^{13}$ The value of contributions is skewed, like net worth, but logging it, double logging it, taking the square

\footnotetext{
${ }^{10}$ Other measures of work behavior (e.g., number of hours worked) for the respondent, the spouse, and the parents did not improve model fit appreciably.

${ }^{11}$ Other measures of respondent's, parents', and spouse's occupations (changes in occupation over time, similarities between respondent and parents/spouse in occupation, etc.) did not improve model fit.

${ }^{12}$ Controlling for residence in New York City, other specific locations, housing price variations, and other regional indicators did not change the results.

${ }^{13}$ Modeling the amount donated to all religious organizations produced comparable results.
} 
American Journal of Sociology

root, and otherwise transforming it did not reduce the skew, because a large proportion of households contribute nothing. Because using the transformed variable did not change the results, I report results of analyses using unlogged contributions to ease interpretation.

Finally, I report results for two models of outcome variables related to childhood influences. These models allow me to explore whether CPs were aware of their parents' financial strategies and whether their families made a direct connection between religion and finances.

EVS independent variables.-In analyses of EVS data, I included a series of dichotomous indicators of childhood religious affiliation with the same coding I used in analyses of the NLSY data. Again, I followed Steensland et al. (2000) rigorously in identifying CPs and in separating white and black CPs. As in the NLSY analyses, however, the results are highly robust to using alternative coding schemes and omitted variables. I also controlled for a series of background, individual, and family traits that affect economic values. I controlled for black and other race. I included a series of respondents' estimates of their parents' financial wellbeing during the respondents' childhood. These estimates are less detailed than information contained in the NLSY, but they are appropriate controls for class in models of adult values. I controlled for region of residence, gender, and marital status with a series of dichotomous variables. I controlled for age with a continuous indicator (age squared was not significant in preliminary investigations). I controlled for four adult household income categories (measured in the prior year), omitting those with less than $\$ 30,000$ in income. The categories highlight economic class differences in values that a continuous measure obscures. I also controlled for full-time employment, education level, two-earner households, and household size to capture elements of social class that are associated with economic values. I do not report coefficient estimates for control variables for EVS analyses, to save space (descriptive statistics for EVS data are included in app. table A1; note that there are differences between the EVS and NLSY samples because the two sample frames are not identical, but the differences are slight).

\section{RESULTS}

Education and Family Behaviors Reduce CP Wealth

Key NLSY data confirm that CPs have very low overall wealth. In 2000, median net worth for CPs in the NLSY was $\$ 26,000$, compared to the full sample median of $\$ 66,200$. The mean net worth for all NLSY respondents was nearly $\$ 200,000$, while the mean for CPs was only $\$ 85,000$. The results in table 1 show that this difference remains in multivariate 
analyses. This table presents the results of four generalized linear models of adult net worth as a function of childhood religion and the control variables. Model 1 is a base model that shows that those raised in $\mathrm{CP}$ families have significantly fewer adult assets than those raised in Catholic and mainline Protestant families, even when a large number of other factors are controlled.

I proposed that education, age at first birth, number of children, and female labor force participation mediate the relationship between religion and wealth for CPs. Model 2 introduces controls for these influences and shows that the effect of the $\mathrm{CP}$ variable is still significant and negative, but relatively smaller than in model $1 .{ }^{14}$ Consistent with my expectations, as education, age at first birth, and female labor force participation increase, so does net worth. Also consistent with my arguments, having any children reduces wealth, and family size has a curvilinear relationship with net worth. I control for gender, age, nonreport of income, and region of residence, but I do not display the estimates, to conserve space. I did not control for age at first marriage, although it might seem relevant. CPs tend to marry early (Hammond, Cole, and Beck 1993; Mosher, Williams, and Johnson 1992), and early marriage can limit education, career advancement, income, and, thus, wealth. However, early marriage also allows couples to join assets, buy a house, and otherwise save together for a longer period. As a result, early marriage typically only reduces wealth slightly, and this effect is overshadowed by the strong influence of current marital status on wealth (Keister 2005). I experimented with controls for age at first marriage, and they confirmed that there was no effect in the models I report. I also experimented with including additional controls for region and denomination. I found that Baptists, particularly those raised in the South, accumulate slightly less wealth than other CPs, but there were no other significant denominational or regional differences among CPs. Finally, controlling for homogamy (on religion, education, earnings, or occupation) did not improve model fit net of the independent effects of these variables. ${ }^{15}$

\section{Race and Class Considerations}

Is religion or race responsible for the strong $\mathrm{CP}$ effect? Blacks tend to be asset poor in the United States (Keister 2004; Oliver and Shapiro 1995),

\footnotetext{
${ }^{14}$ Cox tests confirm that differences in the $\mathrm{CP}$ effect across models are statistically significant.

${ }^{15}$ The NLSY does not include as much detail on Protestant denomination for the spouse as it does for the respondent. The absence of an effect of religious homogamy may reflect differences in the variables.
} 


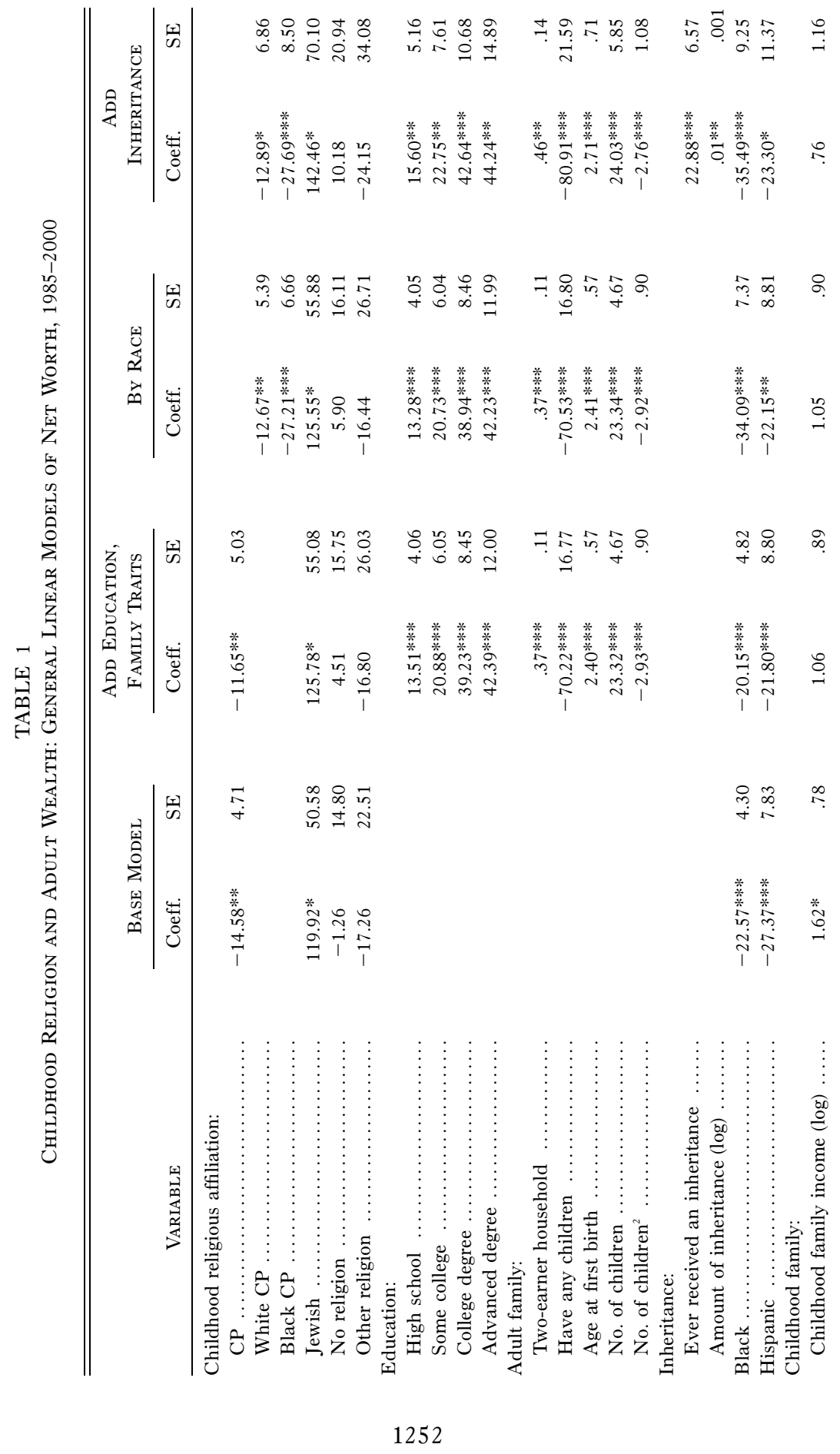




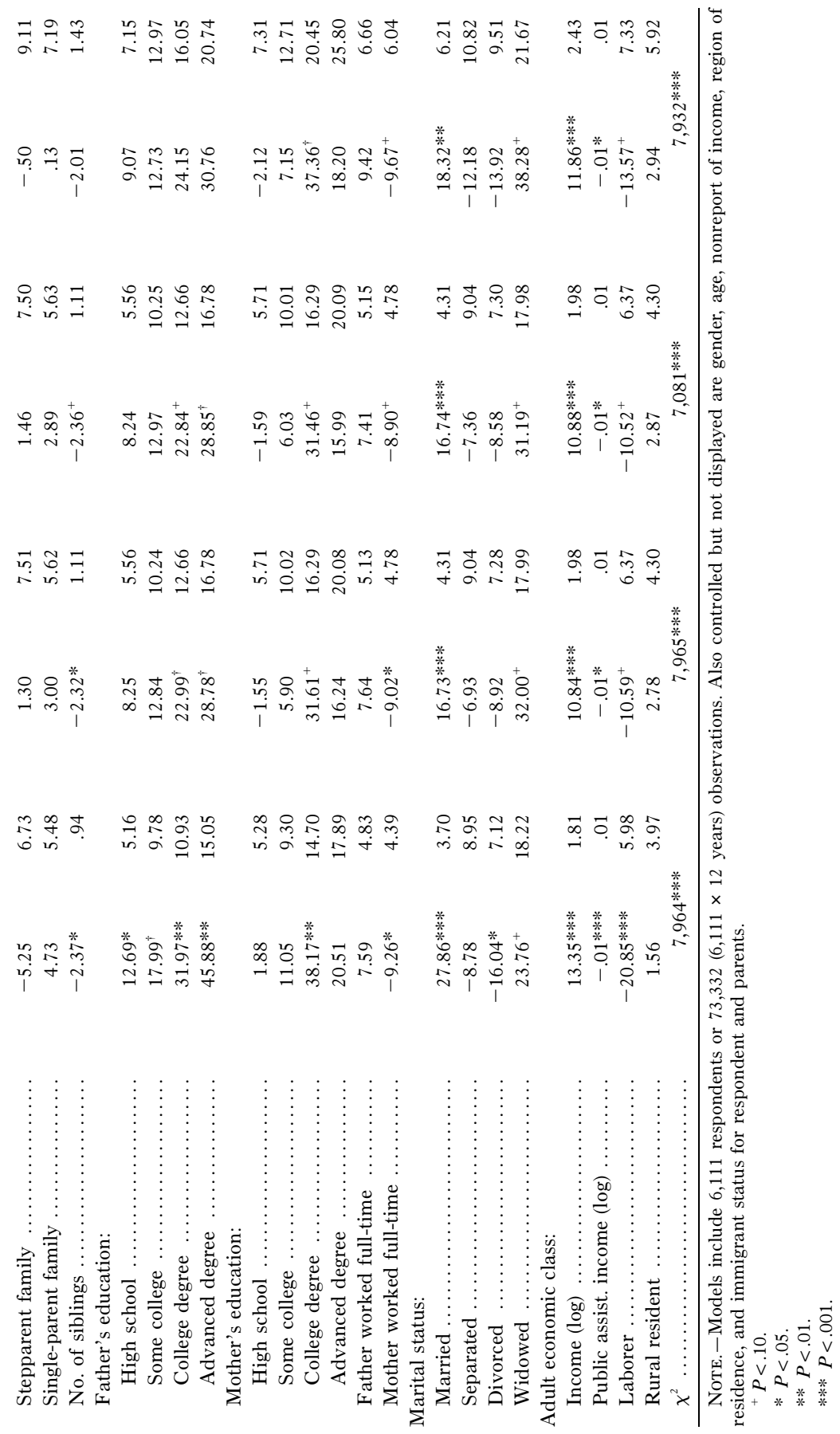


American Journal of Sociology

and many blacks are members of black CP churches (Steensland et al. 2000). Table 1, model 3 includes separate indicators for black and white $\mathrm{CPs}$ to distinguish race and religion effects. The black $\mathrm{CP}$ effect is much larger than the white, but both are strong and significant. This suggests that both black and white CPs accumulate low wealth and that religion is important independent of race. Preliminary analyses using separate equations for blacks and whites indicated that the processes that relate religion to wealth are nearly identical for blacks and whites and that separate models did not provide additional information. There is no relevant, independent effect for Hispanics, as Catholicism is a more common religion for that group than Protestantism.

It is also possible that CPs are members of a socioeconomic class with unique saving behavior, and the strong religion finding is really a class finding. If cultural orientation-including religion-is part of social class, the religion effect indicates that class is related to material well-being. In fact, these findings are important because they demonstrate how an important component of social class correlates with material well-being. Yet my results provide evidence that religion is not a strict proxy for economic class: religion is significant despite controls for class background (parents' education, income, work) and adult class (public assistance receipt, occupation, rural residence). I experimented with other class controls (e.g., childhood public assistance receipt, parent's occupation, childhood residence, income quintile), but none of these improved model fit or reduced the religion effect. Table 1, model 4 includes additional, restrictive inheritance measures, and the religion effect is still strong. Because class is an amorphous concept, it is difficult to conclude with certainty that religion is independent of class. However, these results suggest that religion is an important and unique correlate of wealth ownership.

\section{Lessons from Religious Mobility Patterns}

To this point, I have focused on the relationship between childhood religion and adult wealth, but table 2 introduces models of net worth that control for adult religion (model 1) and religious mobility (model 2). The effect of adult membership in a CP church is negative and significant. This result is consistent with prior research (Keister 2005, 2007) and is robust to using other omitted categories. Although most Americans remain in the same religion from childhood through adulthood (Roof 1989; Sherkat 1991), many do change affiliations, and this change can be instructive. If religion affects wealth, there should be different relative effects for those who either (1) were CP in both childhood and adulthood, (2) left CP churches after childhood (apostates), or (3) became CPs as adults. All three groups should have low wealth compared to mainline Protestants 
TABLE 2

Adult Religion, Religious Mobility, and Adult Wealth: General Linear Models of Net Worth, 1985-2000

\begin{tabular}{|c|c|c|c|c|}
\hline \multirow[b]{2}{*}{ VARIABLE } & \multicolumn{2}{|c|}{ Model 1} & \multicolumn{2}{|c|}{ MOdEL 2} \\
\hline & Coeff. & $\mathrm{SE}$ & Coeff. & $\mathrm{SE}$ \\
\hline \multicolumn{5}{|l|}{ Religious affiliation: } \\
\hline $\mathrm{CP}$ in adulthood $\ldots \ldots \ldots \ldots$ & $-22.93 * * *$ & 5.66 & & \\
\hline \multicolumn{5}{|l|}{ CP mobility (child $\rightarrow$ adult): } \\
\hline Remained CP $\ldots \ldots \ldots \ldots$ & & & $-21.31^{* * *}$ & 6.11 \\
\hline Left $\mathrm{CP}$ denomination ... & & & $-10.50^{\dagger}$ & 7.61 \\
\hline Joined CP denomination & & & $-8.38 * * *$ & .63 \\
\hline Jewish $\ldots \ldots \ldots \ldots \ldots \ldots \ldots$ & $143.05^{*}$ & 60.96 & $142.74 *$ & 60.95 \\
\hline No religion ... & $-19.52 * *$ & 7.39 & $-17.33^{*}$ & 7.68 \\
\hline Other religion & -14.50 & 10.65 & -10.20 & 11.93 \\
\hline \multicolumn{5}{|l|}{ Education: } \\
\hline High school & $12.67 * *$ & 3.96 & $12.54 * *$ & 3.95 \\
\hline Some college $\ldots \ldots \ldots \ldots \ldots$ & $20.31 * * *$ & 5.91 & $20.07 * * *$ & 5.91 \\
\hline College degree...$\ldots \ldots \ldots$ & $37.61 * * *$ & 8.37 & $37.50 * * *$ & 8.37 \\
\hline Advanced degree $\ldots . .$. & $41.33 * * *$ & 11.91 & $41.30 * * *$ & 11.90 \\
\hline \multicolumn{5}{|l|}{ Adult family: } \\
\hline Two-earner household & $.36 * *$ & .11 & $.36 * *$ & .11 \\
\hline Have any children ..... & $-67.68 * * *$ & 16.94 & $-67.59 * * *$ & 16.75 \\
\hline Age at first birth ... & $2.28 * * *$ & .58 & $2.28 * * *$ & .57 \\
\hline No. of children ... & $23.00 * * *$ & 4.65 & $23.08 * * *$ & 4.66 \\
\hline No. of children ${ }^{2}$ & $-2.93 * *$ & .90 & $-2.95 * *$ & .90 \\
\hline Black .............. & $-17.92 * * *$ & 4.81 & $-18.23 * * *$ & 4.66 \\
\hline Hispanic $\ldots \ldots \ldots \ldots \ldots \ldots \ldots$ & $-24.21 * *$ & 8.81 & $-24.11^{* *}$ & 8.99 \\
\hline \multicolumn{5}{|l|}{ Childhood family: } \\
\hline Childhood family income $(\log ) \ldots$ & .94 & .88 & .92 & .89 \\
\hline Stepparent family $\ldots \ldots \ldots \ldots \ldots \ldots$ & 2.48 & 7.55 & 2.75 & 7.54 \\
\hline Single-parent family $\ldots \ldots \ldots \ldots \ldots$ & 4.06 & 5.56 & 4.16 & 5.58 \\
\hline No of siblings $\ldots \ldots \ldots \ldots$ & $-2.34 *$ & 1.11 & $-2.39 *$ & 1.10 \\
\hline \multicolumn{5}{|l|}{ Father's education: } \\
\hline High school ...... & 7.52 & 5.51 & 7.86 & 5.48 \\
\hline Some college ....... & 12.70 & 10.21 & 12.98 & 10.17 \\
\hline College degree $\ldots . .$. & $22.99^{+}$ & 12.62 & $23.16^{+}$ & 12.65 \\
\hline Advanced degree & $27.92^{\dagger}$ & 16.73 & 27.31 & 16.69 \\
\hline \multicolumn{5}{|l|}{ Mother's education: } \\
\hline High school ....... & -1.68 & 5.69 & -1.71 & 5.73 \\
\hline Some college ..... & 5.60 & 10.00 & 5.62 & 10.03 \\
\hline College degree.....$\ldots \ldots$ & $31.46^{+}$ & 16.26 & $31.49^{+}$ & 16.26 \\
\hline Advanced degree....... & 15.21 & 19.97 & 15.00 & 20.01 \\
\hline \multicolumn{5}{|l|}{ Worked full-time: } \\
\hline Father ............. & 6.91 & 5.14 & 6.92 & 5.13 \\
\hline Mother …......... & $-8.91^{+}$ & 4.73 & $-8.96^{+}$ & 4.73 \\
\hline \multicolumn{5}{|l|}{ Marital status: } \\
\hline Married ..... & $17.08 * * *$ & 4.30 & $17.00 * * *$ & 4.30 \\
\hline Separated . & -6.99 & 9.01 & -7.38 & 9.00 \\
\hline Divorced . & -9.15 & 7.27 & -8.84 & 7.29 \\
\hline
\end{tabular}


American Journal of Sociology

TABLE 2 (Continued $)$

\begin{tabular}{|c|c|c|c|c|}
\hline \multirow[b]{2}{*}{ VARIABLE } & \multicolumn{2}{|c|}{ Model 1} & \multicolumn{2}{|c|}{ Model 2} \\
\hline & Coeff. & $\mathrm{SE}$ & Coeff. & SE \\
\hline Widowed & $31.75^{+}$ & 17.87 & $31.89^{+}$ & 17.90 \\
\hline \multicolumn{5}{|l|}{ Adult economic class: } \\
\hline Income $(\log ) \quad \ldots \ldots \ldots \ldots \ldots \ldots \ldots \ldots \ldots$ & $10.56 * * *$ & 1.94 & $10.56 * * *$ & 1.94 \\
\hline Public assist. income $(\log ) \ldots \ldots \ldots$ & $-.01 * *$ & .001 & $-.01 * *$ & .0001 \\
\hline Laborer $\ldots \ldots \ldots \ldots \ldots \ldots \ldots \ldots$ & $-10.81^{+}$ & 6.31 & $-10.92^{+}$ & 6.30 \\
\hline Rural resident $\ldots \ldots \ldots \ldots \ldots \ldots \ldots$ & 3.33 & 4.25 & 3.46 & 4.22 \\
\hline 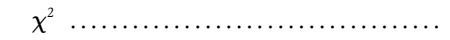 & \multicolumn{2}{|c|}{$2,251 * * *$} & \multicolumn{2}{|c|}{$5,790 * * *$} \\
\hline
\end{tabular}

Note. - The omitted mobility category is for Catholics and mainline Protestant. Models include 6,111 respondents or 73,332 (6,111 × 12 years) observations. Also controlled but not displayed are gender, age, nonreport of income, region of residence, and immigrant status for respondent and parents.

${ }^{+} P<.10$

$* P<.05$

** $P<.01$.

**** $P<.001$.

and Catholics who were never CP. Yet it is likely that those who were $\mathrm{CP}$ in both childhood and adulthood will have the lowest wealth, because long-term affiliation is likely to reinforce the values and behaviors that reduce wealth. The results in table 2, model 2 show that all three groups of CPs have relatively low wealth. The results also confirm that those who remained affiliated with $\mathrm{CP}$ denominations between childhood and adulthood had the lowest wealth of the three groups, suggesting that continuous (or renewed) exposure to $\mathrm{CP}$ values has the strongest effect on adult wealth. Although religious mobility varies by race (Sherkat 1991), I found no significant difference between white and black CPs in the effect of religious mobility on wealth in exploratory analyses. While these findings do not provide conclusive evidence of a causal relationship between religion and wealth, they are consistent with the patterns that should emerge if there is a direct effect of religion on wealth ownership net of other individual and family influences.

CPs Start with an Advantage but Accumulate Slowly

Saving from current income increases wealth directly, and the asset accumulation models in table 3 suggest that CPs accumulate assets during adulthood more slowly than people from other religious backgrounds with otherwise comparable demographic traits. Model 1 shows that those raised in CP families start their adult lives (using 1985 as the base) with more assets than their other demographic characteristics would predict $(\beta=$ 10.90), but they accumulate assets significantly more slowly during adult- 
hood than the omitted category $(\beta=-5.24) .{ }^{16}$ Model 2 includes separate estimates for white and black CPs and shows that both start with relatively high wealth in 1985 and accumulate slowly. I provide separate estimates by race and control for economic class in order to isolate the religion effect from related race and class effects. In both asset-growth models, I control for growth over time by all groups by including a measure of year, and the estimate for the time variable is significant and positive in both models. Yet even with these strict controls, the $\mathrm{CP}$ effects are very strong and highly significant.

Evidence that CPs accumulate assets slowly is central to understanding the $\mathrm{CP}$ wealth disadvantage. I have already shown that $\mathrm{CP}$ education and family traits contribute to their low wealth, and these factors also contribute to the slow accumulation rates evident in table 3 . The results are also consistent with the notion that intergenerational processes contribute to low wealth for CPs: if their parents were not saving and were accumulating few assets, people raised in $\mathrm{CP}$ families may not have learned to save in ways that lead to asset growth. While I do not control explicitly for market conditions and other external events that might affect accumulation, I do control for these influences implicitly by using data on a single (albeit rather wide-ranging) age cohort. Finally, these results also provide preliminary support for my proposal that CPs avoid excess accumulation.

\section{CPs Have Unique Economic Values}

In order to understand why CPs save and accumulate assets differently than others, it is useful to understand how religious affiliation relates to important economic values regarding money, work, and sacrificial giving. The results shown in table 4 are odds ratios for the religion variables from logistic regression equations estimated using the EVS. The table includes results from two separate equations: (1) a model including a single $\mathrm{CP}$ indicator, and (2) a model including separate indicators for white CPs and black CPs. Both models control for all individual and family traits (see app. table A1), but models that separate race do not control for black race. Catholics and mainline Protestants are omitted.

The results shown in table 4 provide strong support for my argument that CPs seek divine guidance in making financial and work decisions and that they avoid accumulation of wealth. They show that CPs, regardless of race, are more likely to pray about financial decisions, to agree

\footnotetext{
${ }^{16}$ The omitted category is Catholics and mainline Protestants, but the findings are robust to using other omitted groups. Table 1 models control for Jewish, no religion, and other religion. I do not display these estimates to conserve space.
} 


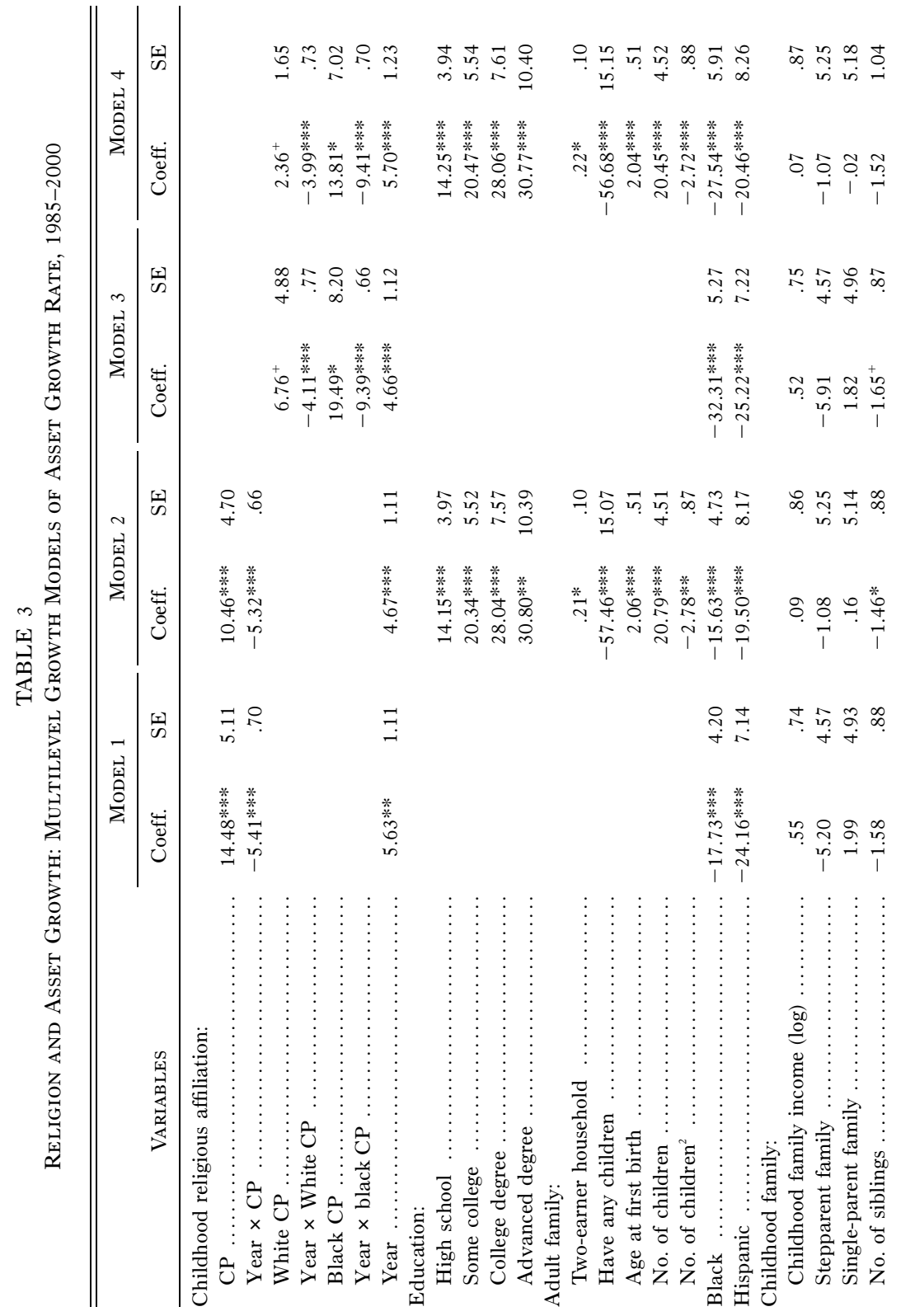




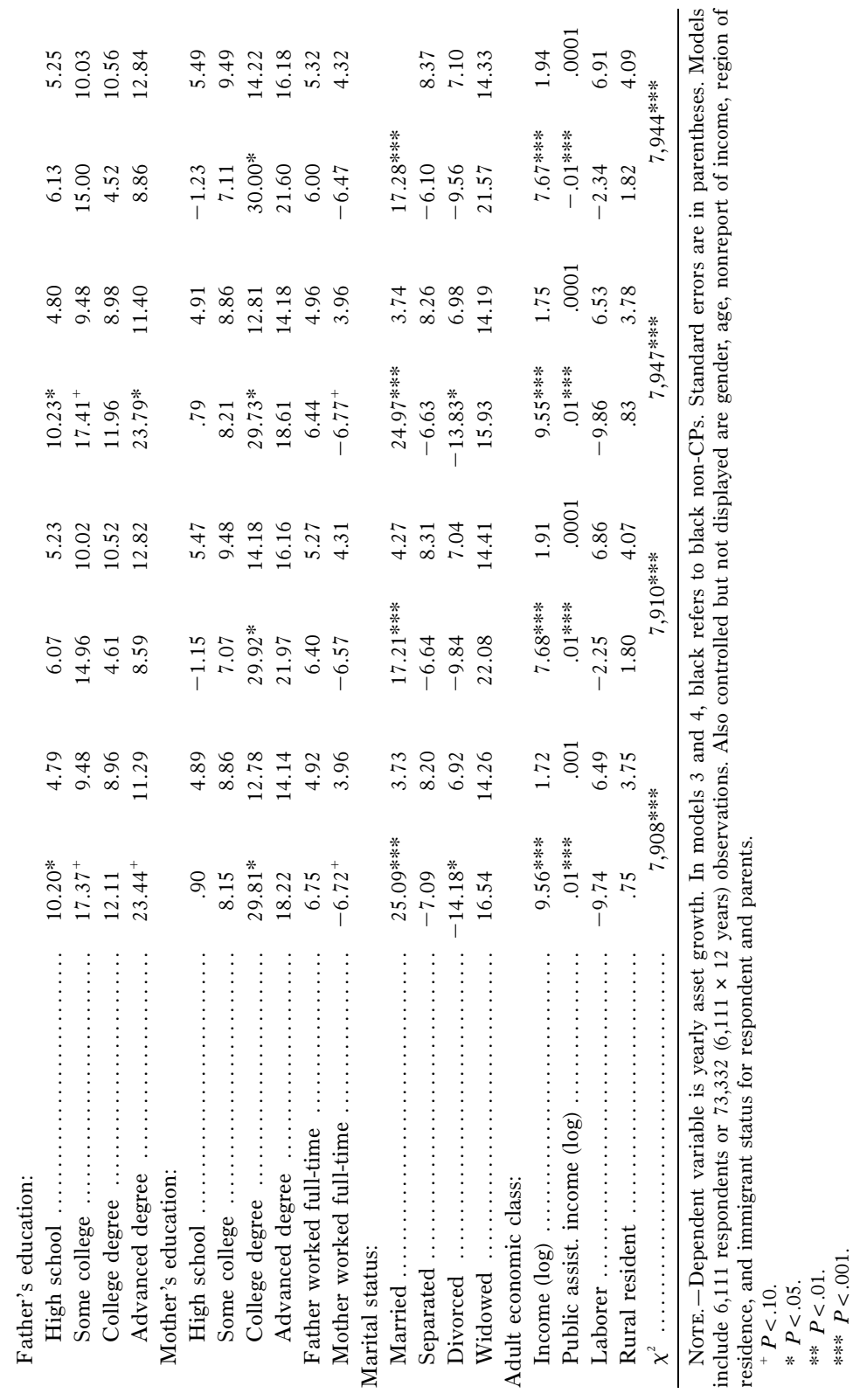


American Journal of Sociology

that the purpose of church is divine guidance, and to thank God for financial blessings. CPs are also more likely to think about the relationship between the Bible and personal finances, to agree that money is the root of all evil, to agree that riches prevent knowing God, and to say that saving for retirement is not important. The results are fairly uniform, with a couple of exceptions. For example, black CPs are not significantly more likely than Catholics and mainline Protestants to agree that they obey God in making work decisions. The other strong results and my exploration of the data suggest that this might be a result of random data error, as black and white CPs are otherwise very similar in their work and financial values. An important caution about these results is that the data include only adults who were in the labor force, rather than a random sample of the entire adult population. However, if nonworking adults had been included, more stay-at-home parents and older Americans would have been represented in the data. It is likely that the results would then have been even stronger, because these nonworking adults tend to have relatively conservative values. Another issue that these data do not allow me to distinguish is whether CPs have unique values because they are religiously conservative or because they accept the principles that $\mathrm{CP}$ churches promote. The EVS data are consistent with what is known about the U.S. population in this regard: very few people who identify themselves as religiously conservative or who claim to accept the Bible as the inerrant word of God do not belong to CP churches. Moreover, if I were able to isolate those respondents who are religiously conservative and not affiliated with a CP church, it is likely that the results would be even stronger.

The Role of Sacrificial Giving

My analyses of the EVS also suggest that CPs have unique attitudes regarding sacrificial giving. Table 4 includes odds ratios for religion indicators from five logistic models regarding the value of sacrificial giving. CPs are more likely to report that the purpose of church is giving money back to God, to feel they should give money to their church, to report that the church is the most significant charity, to agree that the church should encourage giving, and to report that they think a great deal about their responsibility toward the poor. The results are uniformly strong for both white and black CPs. One exception is that the effect of being a black CP on reporting that the church is the most important charity is not significant. Because the other results indicate that white and black CPs are not otherwise noticeably different in the value they place on sacrificial giving, these findings may reflect small sample size for the black CPs rather than a true difference. 
My results also suggest that white CPs donate significantly more to their churches than Catholics and mainline Protestants, controlling for other influences on charitable giving, including income. Table 4 includes coefficient estimates for the religion variables from linear models of the amount given in the prior year to church or synagogue. Modeling the amount donated to all religious organizations produces comparable results. However, the effect of being a black CP is positive but not significantly different from zero. In preliminary explorations, the effect was positive in models that included all variables except income. When I controlled for income, the black CP effect was no longer significant. This finding may reflect the relatively small samples size for blacks, as there is slightly more missing data on income for blacks, decreasing the number of cases for which the model estimates. Alternatively, this finding may suggest that there is a genuine racial difference in tithing. The tithing data in the EVS are high quality and consistent with other data sources that show that CPs are among the most generous contributors to churches and related organizations, in terms of both percentage of household-level income and total congregational receipts (Hoge et al. 1999; Regnerus et al. 1998). An important caveat is that most of these data do show that nearly everyone, regardless of religious affiliation, donates relatively little to religious organizations. Further exploration of tithing patterns is beyond the scope of this paper, but the important role that sacrificial giving may play in creating and maintaining inequality suggests that future research would usefully explore patterns of giving in more depth.

\section{Childhood Financial Lessons}

Many of my arguments assumed that respondents were aware of the financial strategies their parents used and that religious values influenced those strategies. I include two supplemental models (the final two models) in table 4 to explore these important assumptions. The results show that there is a strong, positive relationship between being a $\mathrm{CP}$ and reporting awareness of parents' financial strategies. The results also show a strong, positive relationship between CP religious affiliation and reporting that the childhood family prayed about finances. Indeed, the majority of EVS respondents report that they were aware as children of their parents' financial strategy, and CPs are significantly more likely than others to report being aware of how their parents managed money, even when other individual and family traits are controlled. Because most of the CPs were likely raised in CP families (Roof 1989; Sherkat 1991) and CPs have relatively close parent-child relations (Wilcox 1998), it is not unusual that the adult CPs report a relatively high level of awareness. Moreover, because most of the CPs were likely raised in CP families, it also follows 


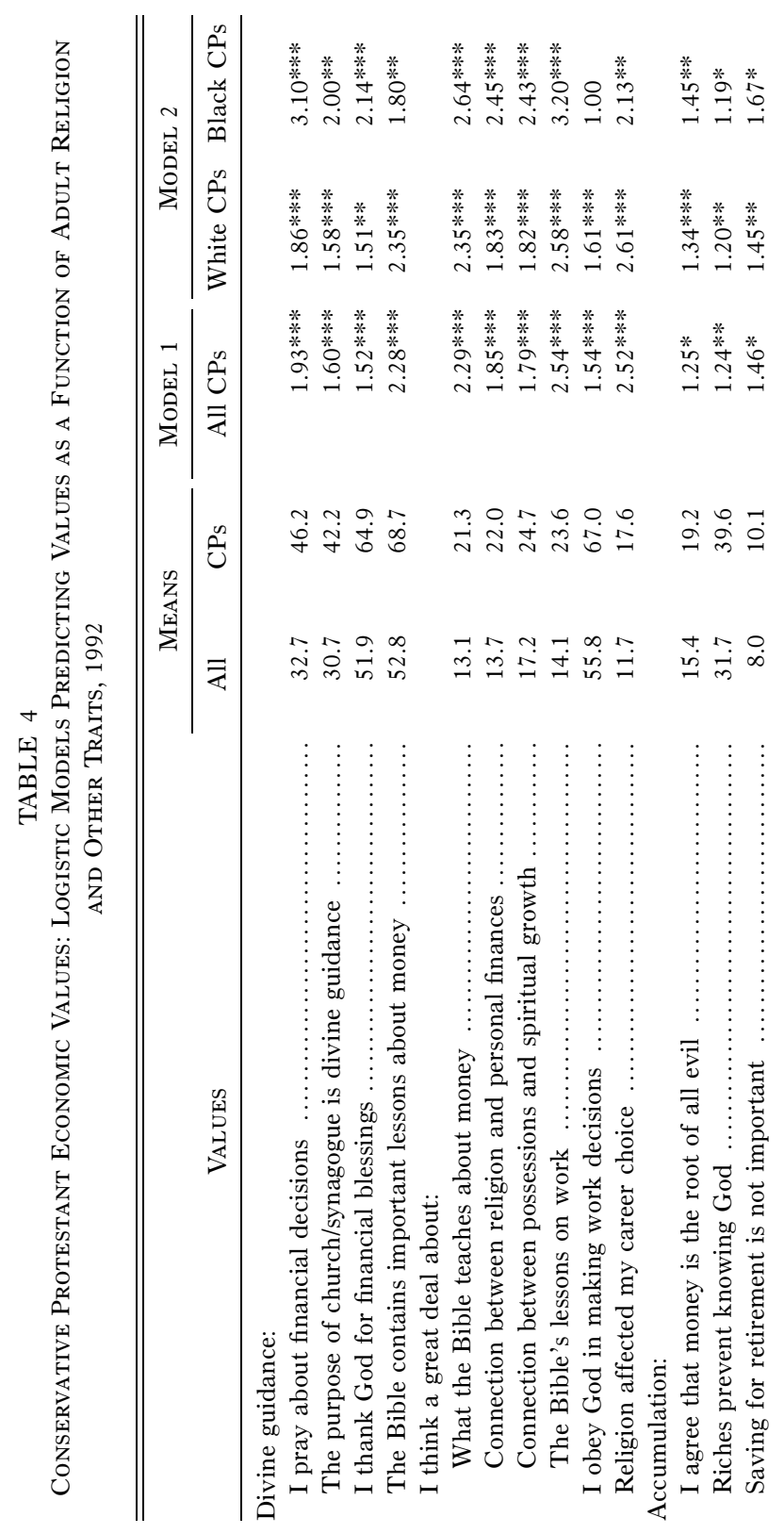

1262 


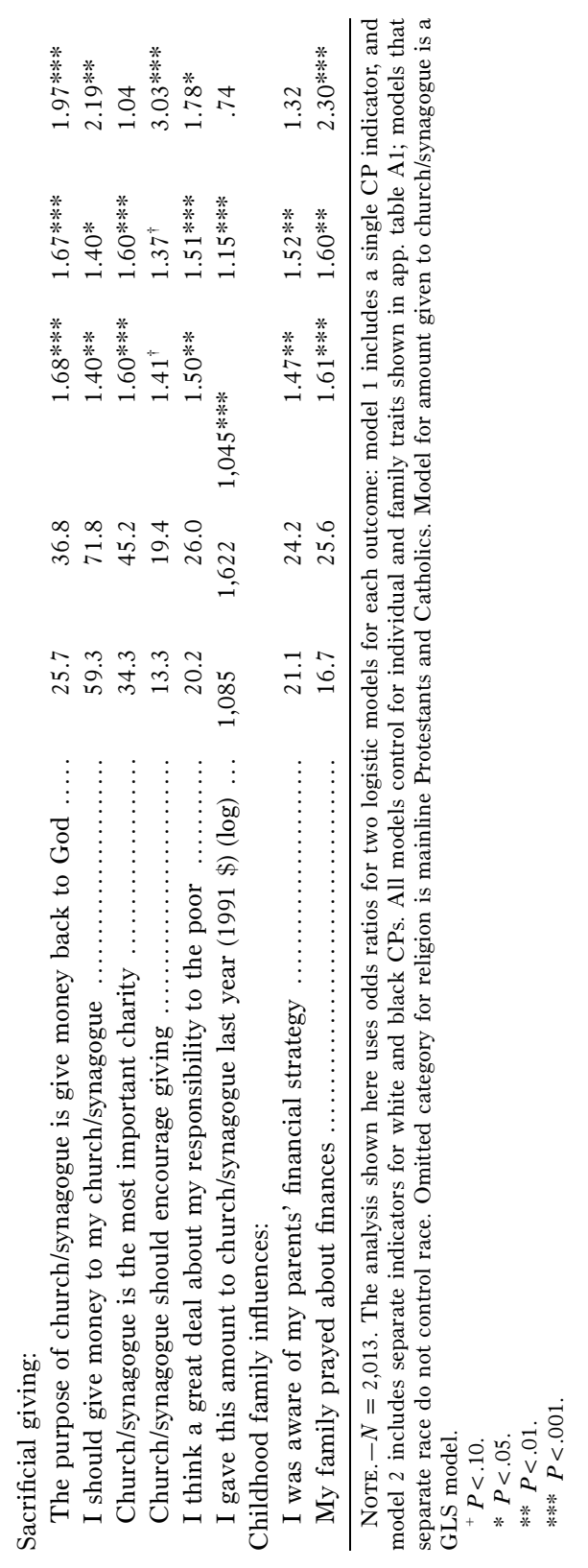

1263 
American Journal of Sociology

that their childhood families would also have valued divine guidance in making financial decisions. While these findings do not provide conclusive evidence of a direct effect of parents' behavior on adult values and financial decision making, they do support the argument that there is a connection.

\section{CONCLUSION}

Sociologists tend to agree that cultural orientation is an important determinant of material outcomes, but it is rare to be able to study this relationship. I explored how religion, an important component of cultural orientation, affects wealth by studying asset accumulation patterns of CPs. I showed that CPs have low wealth regardless of family background and that low educational attainment, early fertility, large family size, and limited female labor force participation are partially responsible. I found that black CPs accumulate lower wealth than white CPs, but the religion effect persisted when I separated black and white CPs. I also explored the role of class in these findings and found that religion is not simply a proxy for economic class. Perhaps more important, the direct effect of religion on wealth remained after I controlled for a large number of other influences. To address the issue of causality, I studied the relationship between religious mobility and asset ownership. I showed that people who were raised $\mathrm{CP}$ and remained $\mathrm{CP}$ as adults had the lowest wealth; those who were raised $\mathrm{CP}$ and left the church had the second lowest wealth; and those who were not raised $\mathrm{CP}$ but joined a $\mathrm{CP}$ church as adults suffered the least disadvantage. These findings do not provide conclusive evidence for a causal effect, but they are consistent with the argument that longterm exposure to $\mathrm{CP}$ values, particularly during the critical childhood years when people learn to save, adversely influences asset ownership.

To further explore the direct effect of CP affiliation on wealth, I then studied the role of religion on asset accumulation rates. I showed that CPs accumulate assets more slowly than others over their adult lives. I found strong evidence that those raised in $\mathrm{CP}$ families begin their lives with no disadvantage given their other traits, but they accumulate assets more slowly than others as they age. Finally, I explored the relationship between religion and the economic values that underlie saving and accumulation, and I showed that CPs have unique values regarding money, finances, and work. My findings provide evidence that CPs consider money to belong to God and, as a result, they seek divine guidance in managing money and avoid accumulation. My results also suggest that CPs value sacrificial giving, and they report giving more to religious causes at all levels of income. Although it is possible that self-reports of tithing 
overestimate true contributions, my findings are consistent with other reports that CPs are relatively generous contributors to churches and related organizations both in terms of percentage of household income and when total congregational receipts are measured (Hoge et al. 1999; Regnerus et al. 1998).

These findings may appear to address the simple relationship between religion and wealth, but they are really about the more central sociological relationship between cultural orientation and material resources. That is, my results identify the process by which one large group remains assetpoor, but the findings and the approach are useful for understanding other distinctive groups and other elements of cultural orientation as well. There is evidence that unique values regarding work and money, combined with amenable demographic behaviors (e.g., educational attainment, stable marriage, and high female labor force participation), allowed Roman Catholics to be upwardly mobile in the wealth distribution in recent decades. However, we know little about the practices that lead some religious groups to accumulate relatively high-value wealth portfolios. For example, Mormons tend to be religiously conservative, but there is little evidence that they are asset poor. Contrasting Mormons with other CPs might provide useful insight into the values that affect saving behavior and wealth ownership. It would also be useful to explore whether some religious groups have closer social networks that compensate for lack of accumulation. Additionally, the growth of suburban megachurches has created an expanding group of people who call themselves conservative Protestants but who tend to have higher SES than the typical American CP. As these churches continue to grow, they will provide a useful contrasting case to the group of $\mathrm{CP}$ denominations that I study. ${ }^{17}$ Similarly, people born in Jewish families tend to have relatively high net worth, but the processes that account for this are not well understood. Moreover, differences in wealth accumulation among Reform, Conservative, and Orthodox Jews could inform understanding of the relationship between religious values and wealth ownership and could help differentiate religious influences from ethnic processes. We also know very little about the effects of other religious beliefs_including Asian religions, Islam, and Eastern Orthodox religions-on wealth. The approach that I used to study CPs might be usefully extended in order to understand these other groups as well.

This approach might also be extended to study how other elements of cultural orientation and corresponding values affect well-being. Few concepts are as pervasive in academic and popular writing as "values," but

${ }^{17}$ Megachurches are very visible, but they still account for a relatively small percentage of CPs in America (Thumma 2005). 
American Journal of Sociology

scholars seldom articulate clear definitions of values or use the concept of values explicitly in their work (Hechter, Nadel, and Michod, 1993). Future research might usefully combine some of the insights derived from empirical work on cultural orientation (including religion) and well-being to understand how values affect decision making, and thus life chances. In particular, it would be useful to clearly articulate the values that derive from a range of cultural orientations and to study how these relate to important decisions regarding education, family life, and finances.

Although the focus of this research was on conservative religious denominations, these findings may have implications for understanding contemporary political developments. Alliances between conservative religious groups (which tend to include moderate-to-low SES people) and conservative political groups (which tend to include high SES people) have raised questions about whether such allegiances violate the apparent economic self-interest of many of those who are involved because of their religious beliefs. The alliances often suggest that religious values prevail over economics in the formation of the alliances and the subsequent political decision making of many alliance members. My findings might help explain this behavior. CPs accept that material possessions belong to God and people are managers of those possessions. I showed that, as a result, CPs tend to seek divine guidance in making important decisions, avoid excess accumulation, and favor using money to support religion. These same values may influence $\mathrm{CP}$ political alliances and voting. That is, $\mathrm{CPs}$ may seek advice from religious leaders in making important political decisions, and they may accept that accumulating excess national wealth is less important than promoting other interests (e.g., right to life, traditional marriage). Finally, the political alliances that $\mathrm{CP}$ churches join often promote the use of federal funds to support religious causes. Given that CPs value using their money to support God's work, it is not surprising that these alliances are appealing to them. Of course, my results do not address these issues, but future research might usefully explore whether there is merit to this extension of my findings.

Finally, and perhaps most important, these findings have significant implications for understanding inequality in the United States and inequality in comparative perspective. The starting point for this study was the observation that wealth inequality is extreme in the United States and the supposition that religion may have some influence on levels of inequality. While I did not study inequality directly, my findings do suggest that if $\mathrm{CPs}$ - a large segment of the American population-began to accumulate wealth more like other groups, we might find that wealth inequality would be reduced. Future research might explore this issue more directly using simulation models to understand how changing saving behavior for CPs affects the wealth distribution. In addition, the United 


\section{Conservative Protestants and Wealth}

States has distinctively high levels of inequality and high levels of religiosity. It is possible that inequality is at least partially explained by religiosity among both $\mathrm{CPs}$ and other religious groups that are chronically asset poor. Future research might also explore this question directly by comparing the United States first to other developed countries and then to developing countries in order to identify the degree to which inequality varies with religion.

\section{APPENDIX}

\section{Descriptive Statistics}

Table A1 shows descriptive statistics for both data sets. There are differences between the EVS and NLSY samples because the two sample frames are not identical, but the differences are slight, as can be seen from the table.

TABLE A1

Means for Exogenous Variables

\begin{tabular}{|c|c|c|}
\hline Variable & NLSY 2000 & EVS 1992 \\
\hline \multicolumn{3}{|l|}{ Religious affiliation: } \\
\hline Protestant $\ldots \ldots \ldots \ldots \ldots \ldots$ & .59 & .56 \\
\hline Conservative Protestant & .35 & .35 \\
\hline White CP ............. & .25 & .28 \\
\hline Black CP ......... & .09 & .07 \\
\hline Mainline Protestant $\ldots \ldots \ldots \ldots \ldots \ldots$ & .23 & .20 \\
\hline Protestant, not specified $\ldots \ldots \ldots \ldots \ldots$ & .02 & .01 \\
\hline Non-Protestant $\ldots \ldots \ldots \ldots \ldots \ldots \ldots \ldots$ & .40 & .44 \\
\hline 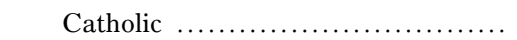 & .33 & .27 \\
\hline Jewish $\ldots \ldots \ldots \ldots \ldots \ldots \ldots \ldots \ldots \ldots$ & .01 & .03 \\
\hline Other religion $\ldots \ldots \ldots \ldots \ldots \ldots \ldots$ & .03 & .04 \\
\hline Undesignated $\ldots \ldots \ldots \ldots \ldots \ldots \ldots$ & . & .03 \\
\hline No religion $\ldots \ldots \ldots \ldots \ldots \ldots \ldots \ldots$ & .03 & .08 \\
\hline \multicolumn{3}{|l|}{ Family background: } \\
\hline Black ..................... & .12 & .09 \\
\hline Hispanic $(\ldots \ldots \ldots \ldots \ldots \ldots \ldots$ & .07 & $\ldots$ \\
\hline 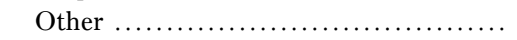 & $\ldots$ & .04 \\
\hline Family income in $1978(\$)^{\mathrm{a}} \ldots$ & 14,600 & . . \\
\hline Stepparent family $\ldots \ldots \ldots \ldots \ldots \ldots \ldots \ldots$ & .08 & \\
\hline Single-parent family $\ldots \ldots \ldots \ldots \ldots \ldots \ldots$ & .13 & \\
\hline No. of siblings $\ldots \ldots \ldots \ldots \ldots \ldots \ldots \ldots \ldots \ldots \ldots$ & 2.95 & \\
\hline \multicolumn{3}{|l|}{ Parents' financial well-being: } \\
\hline Fairly hard up ......................... & . . & .22 \\
\hline A little squeezed $\ldots \ldots \ldots \ldots \ldots \ldots$ & $\ldots$ & .33 \\
\hline Fairly comfortable $\ldots \ldots \ldots \ldots \ldots \ldots$ & $\ldots$ & .40 \\
\hline Fairly well-off $\ldots \ldots \ldots \ldots \ldots \ldots \ldots$ & $\ldots$ & .03 \\
\hline
\end{tabular}


TABLE A1 (Continued)

\begin{tabular}{|c|c|c|}
\hline Variable & NLSY 2000 & EVS 1992 \\
\hline \multicolumn{3}{|l|}{ Region of residence: } \\
\hline East $\ldots \ldots \ldots \ldots$ & . . . & .25 \\
\hline Midwest $\ldots . . . \ldots \ldots$. & . . . & .27 \\
\hline South $\ldots \ldots \ldots \ldots \ldots$ & . . . & .32 \\
\hline West $\ldots \ldots \ldots \ldots \ldots \ldots \ldots \ldots \ldots \ldots \ldots \ldots$ & . . . & .16 \\
\hline \multicolumn{3}{|l|}{ Individual and family traits: } \\
\hline Male.................. & .49 & .50 \\
\hline Age $\ldots \ldots \ldots \ldots \ldots \ldots$ & 39.4 & .41 \\
\hline Married ...... & .51 & .67 \\
\hline Separated ..... & .04 & . . . \\
\hline Divorced $\ldots \ldots \ldots \ldots \ldots \ldots \ldots \ldots \ldots \ldots$ & .12 & .13 \\
\hline Widowed $\ldots . \ldots \ldots \ldots \ldots \ldots \ldots \ldots \ldots$ & .004 & .04 \\
\hline Never married ........ & . . & .17 \\
\hline Family income $(\$)^{\mathrm{b}} \quad$. & 61,200 & \\
\hline Less than $\$ 30,000 \ldots \ldots \ldots \ldots \ldots \ldots \ldots$ & . . & .30 \\
\hline$\$ 30,000-\$ 49,999 \ldots \ldots \ldots \ldots \ldots \ldots \ldots$ & . . & .28 \\
\hline$\$ 50,000-\$ 69,999 \ldots \ldots \ldots \ldots \ldots \ldots \ldots$ & . . & .16 \\
\hline$\$ 70,000$ or more $\ldots \ldots \ldots \ldots \ldots \ldots \ldots$ & . . & .13 \\
\hline Public assist. income (monthly, \$) ..... & 467.87 & . . \\
\hline Laborer $\ldots \ldots \ldots \ldots \ldots \ldots \ldots \ldots \ldots \ldots$ & .12 & . . . \\
\hline Rural resident $\ldots \ldots \ldots \ldots \ldots \ldots \ldots \ldots \ldots$ & .34 & . . . \\
\hline Work full time $\ldots \ldots \ldots \ldots \ldots \ldots \ldots$ & & .78 \\
\hline High school graduate $^{c} \ldots \ldots \ldots$ & .36 & .30 \\
\hline Some college $\ldots \ldots \ldots \ldots \ldots \ldots \ldots \ldots$ & .18 & .30 \\
\hline College graduate...$\ldots \ldots \ldots \ldots \ldots \ldots$ & .12 & .28 \\
\hline Advanced degree $\quad \ldots . \ldots \ldots \ldots \ldots \ldots . . . . .$. & .08 & . . . \\
\hline Two-earner household...$\ldots \ldots \ldots \ldots \ldots$ & .65 & .57 \\
\hline No. of children $\ldots \ldots \ldots \ldots \ldots \ldots \ldots \ldots$ & 1.7 & .02 \\
\hline No. of adullts $\ldots \ldots \ldots \ldots \ldots \ldots \ldots \ldots$ & . . & .02 \\
\hline \multicolumn{3}{|l|}{ Parents' traits: } \\
\hline Father college graduate $\ldots . . . \ldots \ldots \ldots$ & .10 & . . \\
\hline Mother college graduate $\ldots \ldots \ldots \ldots \ldots$ & .07 & . . . \\
\hline Father worked full time $\ldots \ldots \ldots \ldots \ldots$ & .77 & . . . \\
\hline Mother worked full time........... & .40 & . . . \\
\hline \multicolumn{3}{|l|}{ Immigrant status (U.S. born): } \\
\hline Father...$\ldots \ldots \ldots \ldots \ldots$ & .91 & . . . \\
\hline Mother $\ldots . . . \ldots$. & .92 & . . . \\
\hline Respondent $\ldots \ldots \ldots \ldots \ldots \ldots \ldots \ldots \ldots$ & .96 & . . . \\
\hline
\end{tabular}

Notes. $-N=6,111$ for NLSY (National Longitudinal Survey-Youth) data; I used data for 1979-2000 in my multivariate analyses, but I report values in 2000 in this table. $N=$ 2,013 for EVS (Economic Values Survey) 1992. For both columns, some proportions do not sum to 1 because of rounding and missing values. Ellipses in a cell indicate a category not present in that data set.

${ }^{a}$ Income in 1978 dollars. Converted to 2000 dollars using the Consumer Price Index: mean $=\$ 38,200$.

b Total gross 1991 family income from all sources (current dollars)

${ }^{\mathrm{c}}$ Highest level completed. 


\section{Conservative Protestants and Wealth}

\section{REFERENCES}

Alcorn, Randy C. 2003a. The Law of Rewards: Giving What You Can't Keep to Gain What You Can't Lose. Carol Stream, Ill.: Tyndale House Publishers.

. 2003b. Money, Possessions, and Eternity. Carol Stream, Ill.: Tyndale House Publishers.

- 2005. The Practice of Tithing as the Minimum Standard for Christian Giving. Sermon notes, Eternal Perspective Ministries. Sandy, Oreg.

Bartkowski, John P., and Christopher G. Ellison. 1995. "Divergent Perspectives on Childrearing in Popular Manuals: Conservative Protestants vs. the Mainstream Experts." Sociology of Religion 56:21-34.

Burkett, Larry. 2001. Money Matters. Nashville, Tenn.: Thomas Nelson.

Chiteji, Ngina S., and Frank P. Stafford. 1999. "Portfolio Choices of Parents and Their Children as Young Adults: Asset Accumulation by African-American Families." American Economic Review 89:377-80.

- 2000. "Asset Ownership across Generations." Working paper no. 314. Levy Economics Institute, Annandale-on-Hudson, N.Y.

Darnell, Alfred, and Darren E. Sherkat. 1997. "The Impact of Protestant Fundamentalism on Educational Attainment." American Sociological Review 62: 306-15.

Diggle, Peter L., Kung-Yee Liang, and Scott L. Zeger. 1994. Analysis of Longitudinal Data. Oxford: Clarendon Press.

Downey, Douglas B. 1995. "When Bigger Is Not Better: Family Size, Parental Resources, and Children's Educational Performance.” American Sociological Review 60:746-61.

Ellison, Christopher G., and Darren E. Sherkat. 1993. "Conservative Protestantism and Support for Corporal Punishment.” American Sociological Review 58:131-44.

Ellison, Christopher G., and John P. Bartkowski. 2002. "Conservative Protestantism and the Division of Household Labor among Married Couples." Journal of Family Issues 23:950-85.

Ellison, Christopher G., John P. Bartkowsi, and Michelle L. Segal. 1996. "Conservative Protestantism and the Parental Use of Corporal Punishment." Social Forces 74: $1003-28$.

Featherman, David L. 1971. "The Socioeconomic Achievement of White Religio-Ethnic Subgroups: Social and Psychological Explanations." American Sociological Review $36: 207-22$.

Gallagher, Sally K., and Christian Smith. 1999. "Symbolic Traditionalism and Pragmatic Egalitarianism: Contemporary Evangelicals, Families, and Gender". Gender and Society 13:211-33.

Glenn, Norval D., and Ruth Hyland. 1967. "Religious Preference and Worldly Success: Some Evidence from National Surveys." American Sociological Review 32:73-85.

Greeley, Andrew M. 1969. "Continuities in Research on the 'Religious Factor."” American Journal of Sociology 75:355-59.

Greene, William. 2003. Econometric Analysis. 5th ed. New York: Prentice Hall.

Hammond, Judith A., Bettie S. Cole, and Scott H. Beck. 1993. "Religious Heritage and Teenage Marriage." Review of Religious Research 35:117-33.

Hechter, Michael, Lynn Nadel, and Richard E. Michod, eds. 1993. The Origin of Values. New York: Aldine DeGruyter.

Hertel, Bradley R., and Michael Hughes. 1987. "Religious Affiliation, Attendance, and Support for 'Pro-Family' Issues in the United States.” Social Forces 65:858-82.

Hoge, Dean R., Charles Zech, Patrick McNamara, and Michael J. Donahue. 1999. "Giving in Five Denominations." Pp. 3-10 in Financing American Religion, edited by M. Chaves and S. L. Miller. London: Sage Publications. 


\section{American Journal of Sociology}

Kalmijn, Matthijs. 1991. "Shifting Boundaries: Trends in Religious and Educational Homogamy." American Sociological Review 56:786-800.

Keister, Lisa A. 2000. Wealth in America: Trends in Wealth Inequality. New York: Cambridge University Press.

- 2003a. "Religion and Wealth: The Role of Religious Affiliation and Participation in Early Adult Asset Accumulation." Social Forces 82:173-205.

—. 2003b. "Sharing the Wealth: Siblings and Adult Wealth Ownership." Demography 40:521-42.

. 2004. "Family Structure, Race, and Wealth Ownership: A Longitudinal Exploration of Wealth Accumulation Processes." Sociological Perspectives 47: 161-87.

2005. Getting Rich: America's New Rich and How They Got That Way. Cambridge: Cambridge University Press.

. 2007. "Upward Wealth Mobility: Exploring the Roman Catholic Advantage." Social Forces 85:1195-1226.

Kreider, Larry. 2002. God's Perspective on Finances: How God Wants His People to Handle Money. Ephrata, Penn.: House to House Publications.

Lehrer, Evelyn L. 1995. "The Effect of Religion on the Labor Supply of Married Women." Social Science Research 24:281-301.

_. 1996. "Religion as a Determinant of Fertility." Journal of Population Economics 9:173-96.

- 1999. "Religion as a Determinant of Educational Attainment: An Economic Perspective." Social Science Research 28:358-79.

Lenski, Gerhard. 1961. The Religious Factor: A Sociological Study of Religion's Impact on Politics, Economics, and Family Life. Garden City, N.Y.: Doubleday.

Marcum, John P. 1981. "Explaining Fertility Differences among U.S. Protestants." Social Forces 60:532-43.

. 1986. "Explaining Protestant Fertility: Belief, Commitment, and Homogamy." Sociological Quarterly 27:547-58.

Mathews, Shailer. 1896. "Christian Sociology V: Wealth." American Journal of Sociology 1:771-84.

Mosher, William D., Linda B. Williams, and David P. Johnson. 1992. "Religion and Fertility in the United States: New Patterns." Demography 29:199-214.

Oliver, Melvin O., and Thomas M. Shapiro. 1995. Black Wealth/White Wealth. New York: Routledge.

Pearce, Lisa D. 2002. "The Influence of Early Life Course Religious Exposure on Young Adults' Dispositions toward Childbearing." Journal for the Scientific Study of Religion 41:325-40.

Peek, Charles W., George D. Lowe, and L. Susan Williams. 1991. "Gender and God's Word: Another Look at Religious Fundamentalism and Sexism." Social Forces 69: 1205-21.

Regnerus, Mark D., Christian Smith, and David Sikkink. 1998. "Who Gives to the Poor? The Influence of Religious Tradition and Political Location on the Personal Generosity of Americans toward the Poor." Journal for the Scientific Study of Religion 37:481-93.

Roof, Wade Clark. 1989. "Multiple Religious Switching: A Research Note." Journal for the Scientific Study of Religion 28:530-35.

Sandefur, Gary D., and Thomas Wells. 1999. "Does Family Structure Really Influence Educational Attainment?" Social Science Research 28:331-57.

Sherkat, Darren E. 1991. "Leaving the Faith: Testing Theories of Religious Switching Using Survival Models." Social Science Research 20:171-87.

. 2000. "That They Be Keepers of the Home: The Effect of Conservative Religion on Early and Late Transitions into Housewifery." Review of Religious Research 41: $344-458$ 


\section{Conservative Protestants and Wealth}

Sherkat, Darren E., and Christopher G. Ellison. 1999. "Recent Developments and Current Controversies in the Sociology of Religion." Annual Review of Sociology 25:363-94.

Sikkink, David. 1999. "The Social Sources of Alienation from Public Schools.” Social Forces 78:51-86.

Singer, Judith D. 1998. "Using SAS PROC MIXED to Fit Multilevel Models, Hierarchical Models, and Individual Growth Models." Journal of Educational and Behavioral Statistics 24:323-55.

Smith, Christian. 2000. Christian America? What Evangelicals Really Want. Berkeley and Los Angeles: University of California Press.

Steen, Todd P. 1996. "Religion and Earnings: Evidence from the NLS Youth Cohort." International Journal of Social Economics 23:47-58.

Steensland, Brian, Jerry Z. Park, Mark D. Regnerus, Lynn D. Robinson, W. Bradford Wilcox, and Robert D. Woodberry. 2000. "The Measure of American Religion: Toward Improving the State of the Art." Social Forces 79:291-318.

Swidler, Ann. 1986. "Culture in Action: Symbols and Strategies." American Sociological Review 51:273-86.

Thornton, Arland. 1985. "Changing Attitudes toward Separation and Divorce: Causes and Consequences." American Journal of Sociology 90:856-72.

Thumma, Scott. 2005. "Exploring the Megachurch Phenomena: Their Characteristics and Cultural Context." Manuscript. Hartford Institute for Religion Research.

Wilcox, Bradford W. 1998. "Conservative Protestant Childrearing: Authoritarian or Authoritative?" American Sociological Review 63:796-809.

Wolff, Edward N. 2004. "Changes in Household Wealth in the 1980s and 1990s in the U.S.” Working paper no. 407. Levy Economics Institute, Annandale-on-Hudson, N.Y.

Woodberry, Robert D., and Christian S. Smith. 1998. "Fundamentalism, et al.: Conservative Protestants in America." Annual Review of Sociology 24:25-56.

Wuthnow, Robert. 1994. God and Mammon in America. New York: Free Press.

Yamokoski, Alexis, and Lisa A. Keister. 2005. "The Wealth of Single Women: Marital Status and Parenthood in the Asset Accumulation of Young Baby Boomers in the United States." Feminist Economics 12:167-94.

Zelizer, Viviana. 1978. "Human Values and the Market: The Case of Life Insurance and Death in 19th-Century America." American Journal of Sociology 84:591-610.

1989. "The Social Meaning of Money: 'Special Monies." American Journal of Sociology 95:342-77. 